\title{
THE PRESUMPTION OF ADVANCEMENT IN NEW ZEALAND: A CONFUSED AND INCONSISTENT EXISTENCE
}

\author{
Ruiping Ye*
}

This project surveys New Zealand court cases in the last 20 years (2000-2020) concerning monetary or gratuitous land transfers from parents to their children ("parent-child transfer") and examines New Zealand court approaches to the presumption of advancement concerning parent-child transfers. This article examines the status of the presumption in New Zealand, discusses the conceptual understandings of the presumption as revealed in the approaches taken by courts, and investigates the courts' approaches concerning the categories of persons who are subject to the presumption, namely mothers, adult children and sons- or daughters-in-law. This article highlights the weakened status of the doctrine and the confused and inconsistent approaches by courts in engaging (or declining to engage) the doctrine and calls for changes to clarify the understanding of the doctrine and to establish a more consistent approach.

\section{INTRODUCTION}

Monetary transfers between family members are common occurrences in life, especially from parents to their children, and often for the purpose of property acquisition. In such transfers, did the parents intend to give, to lend or to invest the money? Cases of parents transferring real property to their children also occur from time to time. Similar questions arise - did the parents intend to give the property or to retain the beneficial interest of it, the latter meaning that the child would hold the property on trust for the parent? If there is no sufficient documentation about the intention of the transferor, when the relationship breaks down, whether the transfer was a gift, a loan or in trust often becomes the point of contention. To complicate the matter, such disputes often occur not between the

* Lecturer, Faculty of Law, Victoria University of Wellington | Te Herenga Waka. The research for this article was supported by a Victoria University of Wellington Summer Scholarship, with contributions from Greenwood Roche. I thank Karan Venter for providing very able research assistance and colleagues at the Law Faculty who attended a staff seminar on this topic for a fruitful discussion and suggestions for improvement. 
donor parent and the donee child, but between siblings when the parent has passed away, or between the child and his or her partner when a young couple's relationship has broken down. How the courts deal with such situations affects ordinary people's wealth and should guide behaviour in making monetary or land transfers between family members.

This article is a result of surveying New Zealand court cases in the last 20 years (2000-2020) concerning monetary or gratuitous land transfers from parents to their children ("parent-child transfer"). The starting point of 2000 is artificial, but it is considered that 20 years should have generated sufficient cases for analysing recent developments of court approaches on the subject matter. The survey used various combinations of keywords "parent", "father", "mother", "child", "son", "daughter", "property", "house", "home", "loan" and "gift" to search relevant cases. ${ }^{1}$ Among the hundreds of cases yielded from the search, 119 concerned claims over monetary or land transactions involving parent and child. The list was further narrowed down to 83 after excluding transactions between family members who were not in parent-child relationships. The 83 cases included parents purchasing property in a child's name or transferring property to a child, parents transferring money to a child (which in most, although not all cases, were used for property purchase in the child's name), parent and child co-funding the purchase of a property but the title being in the child's name, and the parent or the child funding the purchase but the property being registered in both parties' name. $^{2}$

The first impression on reading the cases was that most cases focused on the examination of evidence and were decided on an evidential basis. It then emerged that the single most important legal issue in the cases involving parent-child transfers was the doctrine of the presumption of advancement, concerning which there was significant confusion and inconsistency across the cases.

The presumption of advancement has been subject to criticism and modification, but it continues to be law in New Zealand. The Law Commission briefly discussed the desirability of retaining the presumption of advancement as part of the review of the Property (Relationships) Act 1976 in 2019. ${ }^{3}$ A commentator had also argued earlier against "relegate[ing] this doctrine to the annals of history" in New Zealand. ${ }^{4}$ Other than that, there has been little study of its operation in New Zealand, or of the relevance or usefulness of the doctrine in resolving disputes concerning parent-child transfers.

This article examines New Zealand court approaches to the presumption of advancement concerning parent-child transfers. It is an empirical study of the application of the doctrine of the

1 The search was comprehensive but not exhaustive.

2 Five of the cases concerned a child's contribution for the parent's benefit.

3 Law Commission Review of the Property (Relationships) Act 1976| Te Arotake i te Property (Relationships) Act 1976 (NZLC R143, 2019) at [5.41]-[5.49].

4 Juliet Chevalier-Watts "The Presumption of Advancement: Is it Time to Relegate this Doctrine to the Annals of History?" (2016-2017) 2:1 LLJ 15. 
presumption of advancement in New Zealand and does not discuss the doctrinal question of whether the presumption should be abolished. The discussion compares the New Zealand situation with the treatment of the presumption in other Common Law jurisdictions, mostly the United Kingdom, Canada and Australia.

Part I introduces the presumption of advancement and the current broad proposition of the doctrine in New Zealand, which sets the context for the discussions in this article. Part II examines the status of the presumption in New Zealand by looking at general attitudes towards the presumption, its relevance to solving parent-child transfer disputes, and the level of difficulty to rebut the doctrine. Part III discusses the conceptual understandings of the presumption as revealed in the approaches taken by courts, including the nature of the doctrine, its relationship with the presumption of resulting trust, and its application to cases of land transfer and of money transfer. Part IV investigates the New Zealand courts' approaches concerning the categories of persons who are subject to the presumption, namely mothers, adult children and sons- or daughters-in-law. This article concludes by highlighting the weakened status of the doctrine and the confused and inconsistent approaches by courts in engaging (or declining to engage) the doctrine. Changes to clarify the understanding of the doctrine and to establish a more consistent approach are called for, but further analysis on possible reforms of the doctrine is beyond the scope of this article.

\section{A BRIEF INTRODUCTION TO THE DOCTRINE OF PRESUMPTION OF ADVANCEMENT}

The Common Law system adopts a longstanding doctrine, the presumption of resulting trust, to deal with gratuitous transfers from one person to another. As is expressed in an oft-quoted passage of Lord Browne-Wilkinson in Westdeutsche Landesbank Girozentrale v Islington London Borough Council: ${ }^{5}$

Where A makes a voluntary payment to B or pays (wholly or in part) for the purchase of property which is vested either in $\mathrm{B}$ alone or in the joint names of $\mathrm{A}$ and $\mathrm{B}$, there is a presumption that $\mathrm{A}$ did not intend to make a gift to B; the money or property is held on trust for A (if he is the sole provider of the money) or in the case of a joint purchase by $\mathrm{A}$ and $\mathrm{B}$ in shares proportionate to their contributions.

The presumption of resulting trust, therefore, declines to recognise a gratuitous transfer as prima facie a gift.

Conversely, as between certain family members, equity employs a different doctrine, the doctrine of the presumption of advancement. This latter presumption presumes that, when gratuitous transfers occur between parties in certain familial relationships, the transferor intends to confer beneficial ownership on the transferee. In other words, while gratuitous transfers between parties outside the accepted categories of relationship (usually referred to as "strangers") are presumed to be trusts,

$5 \quad$ Westdeutsche Landesbank Girozentrale v Islington London Borough Council [1996] AC 669 (HL) at 708. 
gratuitous transfers between certain family members are presumed to be gifts. Both presumptions are rebuttable. $^{6}$

The presumption of advancement was first articulated in 1677 in the case of Grey v Grey, rationalising previous case law on transfers from fathers to sons. ${ }^{7}$ In Grey v Grey, William Grey purchased a property in the name of his eldest son, Thomas Grey. Upon the successive deaths of the son and the father, the question arose as to whether the son took the property absolutely or whether he held the property on trust for the father. The answer to the question would determine who could inherit the property. Some evidence indicated that the father retained control and beneficial ownership of the property, but other evidence indicated the son had the legal and beneficial title and owned the property absolutely. ${ }^{8}$ Lord Nottingham found that the transfer was an advancement, a term that referred to giving an advance share of the parent's estate, ${ }^{9}$ but that has since been used to denote gifting. The reasons for finding advancement were that no trust was implied given "the natural consideration of blood and affection" and that "fathers are bound to provide for their children". ${ }^{10}$ Therefore, "sonship" was deemed sufficient to support the conclusion of an advancement. His lordship also commented on a distinction between situations of children having and having not been advanced, but the distinction has since disappeared. ${ }^{11}$ From this case the presumption of advancement developed.

The doctrine settled on transfers in three types of relationship: father to child, husband to wife, and a person standing in loco parentis to another person. In loco parentis referred to a person standing in the place of "the natural father ... with reference to those parental offices and duties". ${ }^{12}$ It was

6 For a general description of the presumptions of resulting trust and of advancement, see Jessica Palmer "Resulting Trusts" in Andrew Butler (ed) Equity in New Zealand (2nd ed, Thomson Reuters, Wellington, 2009) at 309-312 and 328-330.

7 Grey v Grey (1677) 2 Swans 594 (1677) 36 ER 742. See Jamie Glister "Grey v Grey" in Charles Mitchell and Paul Mitchell (eds) Landmark Cases in Equity (Hart Publishing, Bloomsbury, 2012) 63 at 63 and 84; See also the reference made in Dullow v Dullow (1985) 3 NSWLR 531 at 535.

8 Grey v Grey, above n 7, at 596-597.

9 See the definition of advancement in Henry Campbell Black (Bryan A Garner ed) Black's Law Dictionary (10th ed, Thomson Reuters, Minnesota, 2014) at 63.

10 Grey v Grey, above n 7, at 598.

11 At 599 and 600-601; and Glister, above n 7, at 74-78.

12 Tsun Hang Tey "Reforming the Presumption of Advancement" (2008) 82 ALJ 40 at 57. 
therefore an adaptation of the father-child relationship where the father may be absent and involved relationships such as grandparents to grandchildren or a widowed mother to her children. ${ }^{13}$

In recent decades, many Common Law jurisdictions have abolished the presumption as between spouses, including most provinces of Canada, the state of Victoria in Australia and Northern Ireland, through legislation of family law, relationship property law or marriage law. ${ }^{14}$ In New Zealand, the Matrimonial Property Act 1976 replaced "rules and presumptions of the common law and of equity" concerning transactions between couples, and the presumption of advancement as between "husband and wife" was explicitly abolished. ${ }^{15}$

This has left the presumption being applied in New Zealand, as in most Common Law jurisdictions, only to transfers from a father to his child and the extended situation of in loco parentis. Following the recognition of gender equality, the doctrine has also been applied to mothers. ${ }^{16}$

\section{THE STATUS OF THE DOCTRINE OF PRESUMPTION OF ADVANCEMENT}

\section{A Attitudes Towards the Presumption}

In 1970, Lord Diplock criticised the presumption of advancement as "outdated" as it was based on inferences drawn in "a different social era". ${ }^{17}$ Since Lord Diplock's criticism of the presumption of advancement in Pettitt v Pettitt, the doctrine has from time to time been said to be "outdated", "unnecessary, archaic and even anachronistic" and "seriously anachronistic". ${ }^{18}$

13 See discussions in "The Doctrine of Advancement: Its Application as between Mother and Child" (1939) 5 The Irish Jurist 38 at 38; and The Laws of New Zealand Gifts at [45], note that the doctrine also applies to an adopted father to the adopted child and may apply to a stepfather to the stepchild.

14 The Canadian provinces that have abolished the presumption in this context include Alberta, New Brunswick, Newfoundland and Labrador, Nova Scotia, Ontario, Saskatchewan and Yukon. The United Kingdom parliament purported to abolish the presumption in s 199 of the Equality Act 2010, but that section was never brought into force. Georgina Andrews and Simons Parsons "Challenging Judicial Presumptions when Equity is not Equality" [2018] The Conveyancer and Property Lawyer 10 at 16 states that the provision is of low priority.

15 Matrimonial Property Act 1976, ss 4(1) and 4(2)(a). The Matrimonial Property Act 1976 was later renamed Property (Relationships) Act and several times amended, but the provision abolishing the presumption of advancement remains and is now contained in s 4(3)(a) of the Property (Relationships) Act 1976.

16 This issue will be discussed in Part IVA.

17 Pettitt v Pettitt [1970] AC 777 (HL) at 824 per Lord Diplock.

18 Tey, above n 12, at 41; Andrews and Parsons, above n 14, at 12; and Kevin FK Low "The Presumption of Advancement: A Renaissance?" (2007) 123 LQR 347 at 349. 
This view was adopted by the Family Court in Young $v$ Young. ${ }^{19}$ In that case, a father advanced money to his son and daughter-in-law for the purchase of a matrimonial home by the couple. The Court reviewed Australian authorities Dullow v Dullow and Calverley v Green, and concluded that the presumption was a "legal anachronism" and that "any attempt at expanding its influence should be resisted". ${ }^{20}$ Yet Young $v$ Young represented a minority view in New Zealand.

In most cases, the New Zealand courts have been silent on the continuing relevance of the doctrine. Some explicitly refused to comment on the matter. For example, the High Court in Zhang $v$ $\mathrm{Li}$ resolved the issue on the facts and avoided an "artificial exercise" of analysing the status of the presumption. ${ }^{21}$ Similarly the Court in Woodcock $v$ Woodcock refrained from expressing a view after noting comments about its being "outdated". ${ }^{22}$

Among the few cases that commented on the continuing relevance of the doctrine, more were in support of the doctrine than in opposition. Reeves $v$ Lord noted the doctrine "express[es] some of the most fundamental" of human's biological realities and the law "recognises, indeed flows from, the realities of the human situation"; ${ }^{23}$ Nayaran $v$ Nayaran concluded that it was "premature" to view the doctrine as a "legal anachronism"; 24 and in 2019, the High Court in Li $v W u$ believed that "there is a good reason" for the doctrine. ${ }^{25}$

In general, New Zealand courts appeared to be reluctant to criticise the doctrine, and there is some carefully expressed support. The reluctance of New Zealand courts to echo criticisms is probably because the criticisms were made in a specific context, a context that was less of an issue in contemporary New Zealand. Careful examination of the academic and judicial criticisms of the doctrine reveals that they were largely directed at its implication of gender discrimination and marriage status, such as the application of the doctrine to transfers from husband to wife but not vice versa, and the application to fathers but not to mothers, to married couples but not to de facto partners, and to a man's wife but not to his mistress. ${ }^{26}$ Pettitt concerned a husband claiming beneficial ownership in a matrimonial home registered in the wife's name, and the context was therefore spousal

19 Young $v$ Young [2000] NZFLR 128 (FC).

20 Dullow v Dullow, above n 7; Calverley v Green (1984) 56 ALR 483 (HCA). See Young v Young, above n 19, at 133 .

21 Zhang v Li [2017] NZHC 129 at [19]-[20].

22 Woodcock $v$ Woodcock [2018] NZHC 470, [2019] NZCCLR 10 at [112].

23 Reeves $v$ Lord [2005] DCR 183 (DC) at [23] and [34].

24 Narayan $v$ Narayan [2010] NZHC 1973, [2010] NZFLR 161 at [46].

$25 L i v W u$ [2019] NZHC 2461 at [103].

26 See Alysia Blackham "The presumption of advancement: A lingering shadow in UK law" (2015) $21 \mathrm{~T} \& \mathrm{~T}$ 786 at 789, citing the UK Law Commission's criticism of the presumption on cases in those categories. 
transfer. The two Australian cases cited in Young v Young, namely Dullow v Dullow and Calverley $v$ Green, respectively concerned a transfer from a mother and joint purchase by de facto partners. The context was gender and marital difference, although not all discussions were framed in gender or marital terms. ${ }^{27}$ Most academic criticisms of the doctrine as anachronism are in the context of gender inequality. ${ }^{28}$

In New Zealand the presumption no longer applies to spousal transfers; this reduced the opportunity to discuss the doctrine in the critical light of gender inequality and marital status. Nourse LJ in the United Kingdom Court of Appeal case McGrath $v$ Wallis believed Lord Diplock's criticism was equally applicable to parent-child transfers. ${ }^{29}$ Yet a recent United Kingdom case, Wood $v$ Watkin, warned against "extrapolate[ing]" the treatment of the presumption in a matrimonial property context to parent-child transactions. ${ }^{30}$

Therefore, the doctrine continues to have support in the New Zealand judiciary in the context of parent-child transfers. However, the degree of support needs to be put in context for a meaningful evaluation of its status.

\section{B The Relevance of the Doctrine}

One salient feature of most cases was the lack of written evidence or other direct evidence as to the nature of the transfer, hence the true belonging of the property or money concerned. Despite the difficulties with evidence, in most cases the courts strived to ascertain the intention or the nature of transfer using the limited evidence available, including evaluating relevant conduct, the circumstance of parties, the credibility of witnesses and observation of the person. Few relied on the presumption of advancement.

Of the 83 cases studied, 19 mentioned the presumption of advancement. In case the search on family transfers was not exhaustive, a separate search was conducted using the key phrase "presumption of advancement". The search for 2000-2020 found four more parent-child transfer cases mentioning the doctrine, bringing the total cases mentioning the doctrine to $23 .{ }^{31}$ Two of the 23 cases

27 Dullow v Dullow, above n 7; Calverley v Green, above n 20, discussed in Young v Young, above n 19, at 132133.

28 For example, Andrews and Parsons, above n 14, and Georgina Andrews "The Presumption of Advancement: Equity, Equality and Human Rights" [2007] Conveyancer Prop Law 340 in general; Beth Richards-Bray "Farewell to the Presumption of Advancement" (2010) 15 Cov LJ 27 at 29; and Susan J Heakes "Gifting Real Property to Married Children: The Creation of Legal Fictions to Avoid Section 4(2) of the Family Law Act" (2006) 25 CFLQ 169.

29 McGrath $v$ Wallis [1995] 2 FLR 112 (CA) at 122.

30 Wood v Watkin [2019] EWHC 1311 (Ch), [2019] BPIR 1265 at [96].

31 In addition, four cases involved a relationship other than parent and child - Chang v Lee [2014] NZHC 1091 which involved a transfer from uncle to niece; Mamat v Mamat [2018] NZHC 639, (2018) 19 NZCPR 331 a transfer between brothers; Erni v Brooky [2020] NZHC 3116 from grandparents to granddaughter; and $D v T$ 
mentioned the doctrine only in passing, and were otherwise irrelevant. ${ }^{32}$ Of the remaining 21 cases, some touched on the doctrine but then bypassed it by looking at evidence, some decided against using it because of its undesirability or inapplicability, and others applied it with or without much discussion. ${ }^{33}$ Only four discussed the doctrine in a substantive manner, three of which applied the doctrine, including the two cases that involved transfers to minors. ${ }^{34}$ In total, 10 cases applied the doctrine.

In the United Kingdom it has been found that the doctrine is little used and that it has "limited impact" on decided cases. ${ }^{35}$ In New Zealand the above data show that the doctrine has rarely been engaged, and even among those cases where the doctrine was engaged, it has not been subject to sufficient discussion. The doctrine has been marginalised, although not completely ignored.

\section{The Strength of the Doctrine}

Even where the doctrine was engaged to presume a gift by the parents, there is a further issue of the strength of the doctrine, that is, how difficult or how easy it is to rebut the presumption. Jurists and scholars have from time to time made the point that the presumption was weak or had been weakened. ${ }^{36}$ In New Zealand some judges have expressed similar views, and the presumption of advancement was relatively easy to rebut in most cases when it was engaged.

As early as 1955, the then Supreme Court of New Zealand in Peychers v Peychers indicated that the burden to rebut the presumption was not an onerous one, as the evidence needed not to be "compelling or demonstrative" and only needed to "satisfy the mind of the court". ${ }^{37}$ The Judge in

[2017] NZHC 904 a transfer between two people in a brief co-habitant relationship. The doctrine was mentioned in Chang $v$ Lee in passing and briefly commented on in the other three.

32 Kan v Kan HC Auckland CIV-2008-404-002583, 9 May 2008, an interim judgment; and Taylor v Adair [2018] NZHC 1975 a security for costs case.

33 See details in Parts III and IV of this article.

34 Reid v Castleton-Reid [2019] NZCA 372, [2019] NZAR 1655 refused to apply the doctrine. The three that applied were Woolf v Kaye [2018] NZHC 2191, [2019] 3 NZLR 93; Holster v Grafton (2008) 9 NZCPR 314 (HC); and Reeves $v$ Lord, above $\mathrm{n} 23$. The latter two involved transfers to minors.

35 See Blackham, above n 26, at 792; and United Kingdom Law Commission The Illegality Defence: A Consultative Report (Consultation Paper No 189, 2009) at [6.93].

36 For example, see Andrews, above n 28, at 344; Low, above n 18, at 348; Blackham, above n 26, at 788; Lavelle v Lavelle [2004] EWCA Civ 223, [2004] 2 FCR 418 at [15] and [17]; Laksar v Laksar [2008] EWCA Civ 347, [2008] 1 WLR 2695 at [20]; Close Invoice Finance Ltd v Abowa [2010] EWHC 1920 (QB) at [98]; Pettitt v Pettitt, above n 17, at 814 per Lord Upjohn; and M Dhaliwal Holdings Inc v Pacific Blue Farms Ltd 2014 BCSC 1482, [2014] BCTC Uned 1482 at [55].

37 Peychers $v$ Peychers [1955] NZLR 564 (SC) at 570 
Parlane v Parlane similarly considered that the presumption was "very weak" and easy to rebut. ${ }^{38}$ In some other cases, the strength of the presumption was not discussed explicitly but the court allowed it to be rebutted with slight evidence. In KBM $v R M$, the parents advanced more than $\$ 100,000$ to fund the renovation of the son's home during the son's marriage over a period of about two years. The mother recorded the transfers in her notebook. Her evidence of their practice of lending money to their children and recording advances in a similar manner was accepted as sufficient to rebut the presumption. ${ }^{39}$ The unilateral record did not specify the nature of the transfer, and the affidavit was post-transfer. Therefore, the evidence to rebut the presumption was slight.

In $A D M v D J N$, a mother advanced $\$ 30,000$ to her daughter during the daughter's marriage. There was little contemporaneous evidence to suggest whether the mother's advance was a gift or a loan. The factor that tipped the scale towards successful rebuttal was that the mother had not made any gifts or advances of a similar amount to her other children. ${ }^{40}$ In $L o v L o$, a mother purchased a property with contributions from herself and her two young adult sons. The property was registered in the two sons' names and served as the home for the family of five. The mother's action concerning the "collective" style of family living rebutted the presumption that the deposit she paid was an outright gift to the children. ${ }^{41}$ In $N J G v S S$, a case concerning the relationship property of the son, the son alleged that his father lent money to him and his wife over a period of eight years for family support. The Family Court believed it was "a case of recasting the history rather than genuine debts or loans". ${ }^{42}$ On appeal, the High Court overturned that finding. It ruled that the presumption of advancement was rebutted by the father's affidavit in support of his son's evidence. ${ }^{43}$ The father's affidavit was made for the proceedings and therefore, after the transaction and the breakdown of the young couple's relationship. The reliance on the father's affidavit was against the rule that acts or declarations subsequent to the transfer are admissible as evidence only if they are against the donor. ${ }^{44}$ These cases all indicate the low threshold to rebut the presumption and the weakness of the doctrine.

38 Parlane v Parlane [2011] NZHC 528 at 36.

$39 K B M v R M$ [2012] NZFC 2070 at [23], [32] and [48]-[49].

$40 A D M v D J N$ FC Hastings FAM-2007-020-000111, 17 February 2010 at [59]; Philip Epstein and Lene Madsen "This Week in Family Law" Family Law Newsletters (online ed, Canada, 5 May 2009) observe that Locke $v$ Locke 2000 Carswell BC 1856 (BCSC) identifies several factors for consideration when determining whether a transfer is a loan or a gift, and advances to other child is one of the factors; and in Parlane v Parlane, above $\mathrm{n} 38$, the Judge held that equal treatment of all children was not relevant when the transferor father was alive.

41 Lo v Lo [2020] NZHC 1614 at [28].

$42 N v S$ [2012] NZFC 7043 at [25].

$43 N J G v S S$ [2013] NZHC 914 at [66].

44 See Palmer, above n 6, at 330. 
In the 10 cases that applied the doctrine, the rebuttal was successful in five cases and unsuccessful in five. In the five unsuccessful cases, two concerned a transfer to minors, where the presumption was more difficult to rebut as "classic case[s] where the presumption of advancement is determinative". ${ }^{45}$ In a third case, a dispute between two siblings, the presumption was not rebutted as no admissible evidence was provided to rebut the presumption. ${ }^{46}$ The Judge noted contrasting authorities that the presumption could be rebutted "on comparatively slight evidence" and that the presumption should not "give way to slight circumstances". ${ }^{47}$ This followed earlier judicial comments that the strength of the presumption had been disputed and that the presumption could not be displaced by "slight circumstances". 48

A heightened threshold for rebutting the presumption was seen in two cases. The Family Court in $D G H v P I H$ held that, because no loan agreement was signed at the time of transfer, the presumption was not rebutted. ${ }^{49}$ Similarly, in Zhou $v Y u$, a relationship property dispute, the husband's parents transferred a total of $\$ 638,983$ over a period for the purchase of property. ${ }^{50}$ Despite the large sum involved, the Judge required the husband to prove it was a loan. In contrast, the Court in Linton $v$ Millar held that notwithstanding the presumption, the absence of a gift statement pointed to the lack of intention to gift. ${ }^{51}$ Linton $v$ Millar was one of the majority of cases that chose not to apply the presumption, an indication that the presumption was so weak that it had no bearing on the decision of the case. DHG v PIH and Zhou $v \mathrm{Yu}$ therefore represented a minority approach in comparison to those that saw or allowed a weak presumption or simply bypassed the presumption.

It is natural that the courts' conclusions on rebuttal should be affected by the factual dynamics in the cases and the judges' assessment of the reliability of the witnesses, and that the outcome of the cases be affected by the situation of the parties and the judges' evaluation of where justice of the case should lie. However, framing the reasoning of the cases in terms of the standard for rebutting the presumption and the strength of the doctrine, if not done consistently and appropriately, risks distorting the legal principle. The stark contrast between the approach requiring a gift certificate to establish gift and one requiring a loan document to rebut the presumption raises concern over the

45 Reeves $v$ Lord, above n 23, at [34]. That case involves deposit of money in a minor's account; and Holster v Grafton, above n 34, involving purchasing in minors' names.

46 Woolf v Kaye, above n 34, at [209]-[214].

47 At [185] and [205], citing Laskar v Laskar [2008] EWCA Civ 347 at [20] and Shephard v Cartwright [1955] $\mathrm{AC} 431$ (HL) at 445.

48 Webster v Williams HC Auckland HC19-97, 21 July 1997 at 7.

$49 D G H v$ PIH [2012] NZFC 5535 at [44].

50 Including a small portion transferred by or via the aunt. Zhou $v$ Yu [2015] NZFC 7668, [2016] NZFLR 388.

51 Linton v Millar [2015] NZFC 2048 at [22]. In that case, the parents also made prior loans to the daughter which influenced the outcome of the case. 
inconsistent application of the presumption in New Zealand law. It invites the question of whether it could be a matter of luck for a parent to keep or lose their money, sometimes large sums or amounting to most of their wealth.

Overall, although few judges have criticised the doctrine of presumption of advancement, in general, the doctrine has been infrequently invoked in the past 20 years. Where it was invoked, the strength of the presumption has not been discussed much, and varying standards for rebuttal employed, with most cases adopting easy rebuttal. The doctrine is indeed weak but "not yet extinct". 52

\section{CONCEPTUAL FRAMING OF THE PRESUMPTION}

\section{A The Nature of the Presumption of Advancement}

There are two distinct views about what the presumption of advancement is - is it a substantive rule or an evidential rule? Some scholars see the presumption as the default position for a beneficial interest when the presumption of resulting trust does not apply and a default position "that can be departed from only on proof of a declared trust." ${ }^{53}$ Others see it as an "evidential presumption" which imputes an intention and a "useful tool in filling evidential gaps". ${ }^{54}$ The distinction is important because it affects the application of the presumption. If the presumption is a default position, it is the starting point of the inquiry, and the position is reversed only when it is rebutted. If it is an evidential rule, it is used only when the court could not ascertain intention from available evidence and is the last resort. This determines the inquiry process of the courts and may ultimately affect the substantive outcome of cases.

The proposition of "default position" sees the presumption of advancement as describing a situation where the beneficial interest lies with the holder of the legal interest. This approach is favoured by Australian courts. The High Court of Australia in Calverley $v$ Green held that "[i]t is called a presumption of advancement but it is rather the absence of any reason for assuming that a trust arose", 55 and that the presumption of advancement was not "strictly a presumption at all" but simply an inference to be drawn from certain relationships that prima facie the equitable interest

52 Andrews, above n 28, at 344.

53 Glister, above n 7, at 73; also see Palmer above n 6, at 311, citing C Rickett and R Grantham "Resulting Trusts - a rather Limited Doctrine" in P Birks and F Rose (eds) Restitution and Equity, Volume 1 (Mansfield Press, Oxford, 2000) 39 at 39.

54 Lauren Blake and Caitlin MacDonell "Baryla v Baryla: The Presumption of Advancement in the Family Law Context" (2020) 39 Estates Trusts \& Pensions Journal 99 at 101; Tey, above n 12, at 57; also see Krasa Bozinovska "Elder Law: Rethinking the Presumption of Advancement in Contemporary Australia" (2019) 62 LSJ 78 at 78-79 and James Brightwell "Good Riddance to the Presumption of Advancement" (2010) 16 T \& T 627 at 629 .

55 Calverley v Green, above n 20, at 492 per Mason and Brennan JJ, quoting Fullagar and Windeyer JJ in Martin v Martin (1959) 110 CLR 297 (HCA) at 303. 
followed the legal estate. ${ }^{56}$ The Supreme Court of Western Australia in Anderson v McPherson (No 2) traversed the question and similarly concluded that the presumption was "to preclude a resulting trust from arising for the purchaser" and "is simply a circumstance in which 'the presumption of resulting trust' does not arise." 57 This approach accords with the original articulation in Grey $v$ Grey, which ruled that the relationship between the father and the son meant that no trust arose unless the father declared it in writing or it was proved on other direct evidence. ${ }^{58}$

It follows that the question for a case of gratuitous transfer is simply "whether 'the presumption of advancement' applies", ${ }^{59}$ which will then turn on examination of the type of relationship at issue. ${ }^{60}$ If the relationship dictates the application of the presumption of advancement, the beneficial interest belongs to the donee unless the donor's intention to the contrary is proved. If the relationship does not fall within an accepted category of relationship, the presumption of resulting trust applies, and the beneficial interest remains with the donor unless an intention to give is proved.

The contrasting view of the presumption of advancement sees it as a rule to fill evidential gaps or to impose the onus of proof. This view has strong support from Pettitt, where Lord Diplock held that the doctrine was "based upon inferences of fact which an earlier generation of judges drew as to the most likely intentions". ${ }^{61}$ Lord UpJohn in the same case agreed that it was "no more than a circumstance of evidence which may rebut the presumption of resulting trust". ${ }^{62}$ After Pettitt the presumption was said to be reclassified "as a judicial instrument of last resort", especially in the United Kingdom, and "a fallback position" where there was no sufficient evidence. ${ }^{63}$ In Australia, expressions of its being an evidential rule also exist, although the "dominant Australian approach" is said to be treating the presumption as a default legal position. ${ }^{64}$ For example, Deane $\mathrm{J}$ in Calverley $v$ Green opined that the presumption served the "function as a civil onus of proof and operated to resolve

56 Calverley v Green, above n 20, at 500 per Deane J.

57 Anderson v McPherson (No 2) [2012] WASC 19, (2012) 8 ASTLR 321, at [133] citing Dixon CJ in Wirth v Wirth (1956) 98 CLR 228 (HCA) at 237, and at [136].

58 Grey v Grey, above n 7, at 600; also see the discussion of Grey v Grey in Glister, above n 7, at 73.

59 Anderson v McPherson (No 2), above n 57, at [138].

60 See analysis at [139]-[150].

61 Pettitt v Pettitt, above n 17, at 824 per Lord Diplock.

62 At 814 per Lord Upjohn.

63 See McGrath v Wallis, above n 29, at 115; Andrews and Parsons, above n 14, at 11; and Brightwell, above n 54 , at 629 .

64 Anderson v McPherson (No 2), above n 57, at [136]. 
a factual contest" where the evidence was "either uninformative or truly equivocal". 65 This view means that the presumption is applied only as a last resort.

The default position view accords with the original articulation in Grey $v$ Grey, ${ }^{66}$ while the evidential rule view is a later development.

A less-taken middle ground was that the presumption was the starting point for inquiry, but it nevertheless is an evidential rule. In the 1950s, the then Supreme Court of New Zealand in Peychers $v$ Peychers stated that the presumption was "in essence" "a rule as to the burden of proof, furnishing the starting-point from which the inquiry must begin"; yet the final decision of the case must "rest on intention" which was "a pure question of fact to be determined in the light of all the relevant circumstances." 67 This view appears to be self-contradictory, since a starting point of presumptive gift requires active rebuttal to dislodge it, while a finding of intention necessarily looks at the balance of probabilities without any presumptive view. Interestingly, the Supreme Court of Canada in Pecore $v$ Pecore has adopted a similar approach. That Court noted that the normal approach was for the trial judge to commence the enquiry "with the applicable presumption" but then to weigh up the evidence and decide the case on the balance of probabilities. ${ }^{68}$ Glister found it "difficult to see" a point in this approach. ${ }^{69}$

The New Zealand cases reveal little support for the default position view and more for the view as an evidential rule, although there has been little discussion of this issue. This contrasts with the explicit discussions of the issue and the strong preference for the default position view by Australian courts. Among the few New Zealand cases which discussed the issue, Parlane v Parlane was typical in seeing the presumption as a device to "infer a generally applicable intention to fill a gap left by the absence of evidence" and therefore the starting point was to review the facts to ascertain the intention - the presumption was applicable only when the evidence was insufficient to help identify an intention. ${ }^{70}$ Most recently, the Court of Appeal in Reid $v$ Castleton-Reid noted that the presumption was "just that, a presumption as to the most likely inference of fact in the absence of evidence to the contrary". ${ }^{71}$

65 Calverley $v$ Green, above n 20, at 499 per Deane J.

66 Grey v Grey, above n 7; and see the discussion of Grey v Grey in Glister, above n 7, at 73.

67 Peychers $v$ Peychers, above n 37, at 569-570.

68 Pecore v Pecore [2007] SCC 17 at [44].

69 Glister "The Presumption of Advancement to Adult Children" [2007] Conveyancer Prop Law 370 at 375.

70 Parlane v Parlane, above n 38, at [36].

71 Reid v Castleton-Reid, above n 34, at [86]. 
Some cases have not explicitly discussed the nature of the presumption, but they decided that the factual findings were sufficient to determine the outcome of the case and therefore, there was no need to engage the presumption. ${ }^{72}$ As such they implicitly agreed with the view that the presumption was a last resort.

There were also cases that applied the presumption as a matter of course which implicitly suggested the Judges' position that the presumption was the starting point. However, those cases usually did not discuss the conceptual question of the nature of the presumption, and there is no way of knowing whether the judges would have taken the same approach if the matter was examined.

The different understandings of the nature of the presumption of advancement determine the approaches to when, if at all, to apply the presumption and determine the outcome of cases. The presumption started as a default position of beneficial interest following the legal estate, but eventually shifted to the less important position of an evidential rule. It is a manifestation of the weakening of the doctrine. While Australian courts have mostly favoured the traditional default position, New Zealand courts have leaned towards treating the presumption as a last resort. However, the approaches across the board indicate inconsistent understanding, and in-depth discussions or explicit articulation have remained few.

\section{B The Relationship with the Presumption of Resulting Trust}

A question that very closely links to the nature of the presumption of advancement is that of its relationship with the presumption of resulting trust. In essence it is a different expression of the same question.

In the exposition about the doctrine of the presumption of resulting trust in Westdeutsche Landesbank Girozentrale v Islington London Borough Council, Lord Browne-Wilkinson noted that that presumption could be "easily rebutted $\ldots$ by the counter-presumption of advancement". ${ }^{73}$ The question then arose: Does the presumption of advancement exist as a sub-rule of the presumption of resulting trust, being one way to rebut the latter presumption; or does it exist at all, if it expresses a situation where the legal title and beneficial title belong to the same person, which is the natural state of affairs without the intervention of equity ${ }^{74}$ In other words, if a father transfers a property to his son, does it mean a presumption of resulting trust is rebutted by the relationship between the two, or does it mean no presumption of any sort arises given the relationship between the two? Glister argues that this question is important because, if the presumption of advancement exists as a rebuttal to the presumption of resulting trust, to defeat the rebuttal the donor only needs to prove no intention to give

72 For example see Zhang $v$ Li, above n 21; Linton v Millar, above n 51; and Young v Young [2020] NZHC 3054 [Young v Young (2020)].

73 Westdeutsche Landesbank Girozentrale v Islington London Borough Council, above n 5, at 708.

74 See Jamie Glister "Is There a Presumption of Advancement" (2011) 33 Sydney L Rev 39 at 42. 
and does not need to prove a trust was intended or established or any other intention. Once the presumptive advancement is defeated, the position will revert to trust, which was the presumption, and was not rebutted. In contrast, if the presumption of advancement merely describes a situation where the presumption of resulting trust does not apply (in other words, a default legal position), to negate a gift the donor usually has to establish that the transfer was made on trust. ${ }^{75}$ That is to say, to dislodge a legal position one has to prove a trust, while to rebut a presumption of gift one only needs to negate gift.

After traversing the reasoning in Grey $v$ Grey, Glister concludes that: ${ }^{76}$

The presumption of advancement is not a presumption of intention that can be rebutted by evidence inconsistent with that intention; instead, it is a default position that can be departed from only on proof of a declared trust. In other words, the presumption of advancement is the absence of a presumption of resulting trust, not a counter part of it.

The New Zealand cases have not paid attention to this subtle but important distinction, which was consistent with the courts not seeing the presumption as the default position. Suffice it to say that no case under survey required an express trust. Further, there seemed to be slight confusion about the relationship between the presumptions of advancement and of resulting trust in occasional cases.

If the presumption of advancement is a sub-rule of the presumption of resulting trust, does it mean that the presumption of advancement could not exist independently from the presumption of resulting trust - that is, where no resulting trust was alleged, no presumption of advancement could be engaged? The Family Court's approach in Young $v$ Young pointed to an affirmative answer. In that case, the dispute was about whether the transfer was a loan or a gift, rather than a trust. The Judge was of the view that since no trust was at issue, the presumption of advancement was not engaged. ${ }^{77}$

The approach in Young $v$ Young departed from the original exposition of the presumption of advancement in Grey v Grey. Although Grey concerned a dispute about whether property was held on trust or was a gift, Lord Nottingham did not formulate it as a rebuttal or a sub-rule of the presumption of resulting trust. His Lordship noted that "those acts which would imply a trust in a stranger, will not do so in a son", and that "therefore it is not reasonable that the father's perception ... should turn a presumptive advancement into a trust". ${ }^{78}$ The exposition indicated that the presumption of advancement arose in its own right and as an alternative to the presumption of resulting trust where a special relationship existed between the parties. The presumption of

75 At 40 .

76 Glister, above $\mathrm{n} 7$, at 73 .

77 Young $v$ Young, above n 19, at 134.

78 Grey $v$ Grey, above n 7, at 598 and 599. 
advancement excludes the application of the presumption of resulting trust; it is not a sub-rule of the presumption of resulting trust and does not rely on the latter to exist.

The second approach went the opposite way and treated the presumption of advancement as parallel to the presumption of resulting trust, both of which could be applied concurrently. In Lov Lo, the Judge considered both presumptions and found that the presumption of advancement was rebutted and the presumption of resulting trust was "reinforced". ${ }^{79}$ The issue with this approach is that it ignored the fact that the two presumptions are mutually exclusive. They apply to different situations, namely transfers between "strangers" and transfers between parties with a certain relationship. Parties are either "strangers" or not, and as a result only one presumption can be applied.

The approaches in Young $v$ Young and Lo $v$ Lo were occasional incidents, but by both denying the application of the presumption when no trust was claimed and applying both presumptions concurrently, this showed the courts' confusion about the relationship between the presumptions of resulting trust and of advancement.

\section{Distinction between Land and Personalty}

A further issue worth examination is whether a distinction should be drawn between transfer of real property and transfer of money in applying the presumption of advancement. Lord Upjohn in Pettitt unequivocally noted that the doctrine applied "equally to personalty". ${ }^{80}$ This means that there is no distinction between transfers of land and of money. However, the adoption of Torrens indefeasibility of title does complicate the matter, which is little discussed by New Zealand courts in presumption of advancement cases.

The Australian courts distinguished parental transfer of money for the purchase of property from voluntary transfer of property - the former attracts the presumption of advancement while most states treat voluntary transfer of land as outright gifts, unless invalidated by proven "undue influence or unconscientious dealing". ${ }^{81}$ The latter situation attracts neither the presumption of advancement nor the presumption of resulting trust. The distinction is profound because, as discussed in Section B, the presumption of advancement can be rebutted by the parent's lack of intention to gift, while in cases of no presumption there needs to be a declared trust or unconscionable conduct on the part of the child to invalidate the child's ownership. This is consistent with the indefeasibility of title under the Torrens system.

79 Lo v Lo, above n 41, at [28].

80 Pettitt v Pettitt, above n 17, at 814 per Lord Upjohn.

81 Susan Barkehall Thomas "Parent to Child Transfers: Gift or Resulting Trust?" (2010) 18 APLJ 75 at 78 and 80. 
In New Zealand there has been no explicit discussion of the applicability to transfer of land and transfer of money, but of the cases that concerned the transfer of land, few engaged the presumption of advancement.

To start with, of the cases studied concerning parent-child transfers, most concerned monetary transfers. ${ }^{82}$ In contrast to monetary transfers where written statements were few, most land transfers had accompanying deeds and were resolved on an evidential basis. Out of the cases that discussed the presumption of advancement, all but three cases concerned monetary transfers. Among the three land transfer cases, Holster $v$ Grafton concerned the purchase of a house in the names of minors; the presumption of advancement was engaged and was not rebutted. ${ }^{83}$ Therefore, the children retained the ownership, an outcome consistent with that under the Torrens system. The second land transfer case involved a purchase in the name of two teenage children; both the presumptions of advancement and of resulting trust were engaged, indicating some confusion. ${ }^{84}$ In the third case, Young $v$ Young (2020), the mother and son were both registered proprietors. The Court found that the mother and her deceased husband purchased the property and the son did not contribute to the deposit or mortgage. The Court found that the son held the land on trust based on findings of fact and noted in passing that the facts countered the presumption of advancement. ${ }^{85}$

Apart from Holster $v$ Grafton, the only other land transfer case in the survey found to have preserved the registered proprietor's title was Ford $v$ Strangwick. ${ }^{86}$ The Judge found "overwhelming" "objective evidence", including written contemporaneous records, pointing to an unconditional gift. ${ }^{87}$ The presumption of advancement was not mentioned in that case.

Some land transfer cases did not discuss the presumption of advancement but engaged other legal principles. In Toman $v$ Toman, an elderly mother transferred her house to the son. The Court looked at the circumstance of the transfer, found no strong motive to gift from the circumstance of the transfer, preferred the mother's evidence and claim for resulting trust, and invoked a "presumption of undue influence". ${ }^{88}$ That presumption was considered in a House of Lords decision, but scholars cautioned against such a presumption. ${ }^{89}$ In Murphy $v$ Murphy, a mother and her son were the

82 Most of the land transfer cases involved disputes between parent and child.

83 Holster v Grafton, above n 34.

84 Lo v Lo, above n 41. Applying both presumptions was incorrect, as discussed in Section B.

85 Young $v$ Young (2020), above n 72, at [63].

86 Ford v Strangwick [2020] NZHC 2163. Not all land transfer cases in this study concerned title; some concerned partial forgiveness of debt.

87 At [44], [46] and [69].

88 Toman v Toman HC Wellington CIV-2009-485-000765, 11 August 2009.

89 On the ground of "unjustifiable infringement" on the autonomy of individuals to enter binding legal transactions. See discussions in Emily Knowles and Jane Knowler "The Presumption of Undue Influence: 
registered proprietors of a property. The Court introduced a "presumption of ownership" on the basis of his legal title, but the presumption was rebuttable and was rebutted by the Court's findings of fact. ${ }^{90}$ The ownership was a recognition of the effect of the registered title but holding it as a rebuttable presumption is inconsistent with the Torrens principle of indefeasibility which can be attacked only if recognised exceptions apply.

People usually treat land transfers with more caution than monetary transfers, as land is a unique asset with high values. Legal advice and better documentation can reduce disputes after transfers. This may explain why most parent-child transfers concerned monetary transfers. Further, that most cases mentioning or engaging the presumption of advancement were monetary transfer cases suggests that courts tended not to engage the presumption of advancement in land transfer cases. A distinction between monetary and land transfers may have been implicitly drawn, although the line was not absolute. However, the use of presumptions of advancement, of undue influence and of ownership in different cases shows the lack of a clear rule concerning gratuitous land transfer between parents and adult children. The effect of the indefeasibility of a Torrens title was not considered and registered proprietors' titles were defeated by means not prescribed in the Land Transfer Act.

The inconsistent treatment in cases indicates confusion in New Zealand concerning the presumption of advancement, its relationship with the presumption of resulting trust, and the relevance of the distinction between realty and personalty.

\section{TO WHOM DOES THE PRESUMPTION APPLY}

The doctrine of the presumption of advancement applies to transfers by a father to his child and a person in loco parentis to another. In recent years, New Zealand courts largely had no problem in applying the presumption to mothers, but the application was not consistent. There also exists division concerning whether it applies to adult children. Further, courts have taken simplistic approaches when applying the doctrine to the situation where a son- or daughter-in-law ("child-in-law") is involved.

\section{A Mothers}

The question of whether transfers from a mother to her child could trigger the presumption was considered by courts at least by the early $1900 \mathrm{~s},{ }^{91}$ and the result depended on whether the mother assumed the obligation to provide for her children, which the court said very slight evidence would

Elderly Parents, their Adult Children and Transactions between Them" [2014] RLR 35 at 37 . The House of Lords case was Royal Bank of Scotland Plc v Etridge (No 2) [2001] UKHL 44, [2002] 2 AC 773.

90 Murphy v Murphy [2013] NZHC 217.

91 See discussions in "The Doctrine of Advancement: Its Application as between Mother and Child", above $n$ 13. 
justify. ${ }^{92}$ This essentially means the presumption applies if the mother is in loco parentis, and does not directly recognise the presumption as applicable to mothers in their own right.

In New Zealand, the Guardianship Act 1968 (repealed) provided the basic position that both a father and a mother have the guardianship of a child. ${ }^{93}$ This is now provided in s 17 of the Care of Children Act 2004. This means that a mother enjoys the same rights and obligations as a father and is no longer simply in loco parentis. With the recognition of gender equality and basic human rights in modern society, the extension of the presumption to a mother is both logical and legally mandated. ${ }^{94}$ The High Court of Australia laid down the law to extend the presumption to mothers in Nelson $v$ Nelson in 1995, after obiter dicta to that effect in Calverley $v$ Green and Dullow $v$ Dullow. ${ }^{95}$ The Supreme Court of Canada in Pecore $v$ Pecore articulated the same principle. ${ }^{96}$ It was an obiter dictum but has been accepted as the law in Canada. ${ }^{97}$

The situation in the United Kingdom is less certain. As of 2008, it was found that the dominant view in the United Kingdom was that the presumption did not apply to mothers. ${ }^{98}$ Subsequent to the finding, in two 2010 cases it was held that the presumption applied to mothers as to fathers. Close Invoice Finance Ltd $v$ Abowa examined authorities in both the United Kingdom and Australia as well as academic commentaries, and declared support for the application to mothers. ${ }^{99}$ Similarly, Musson $v$ Bonner held that the presumption applied to mothers as it did fathers. ${ }^{100}$ However, in 2019 the Judge in Smith $v$ Crawshay expressed uncertainty in this regard, citing "significant authorities" from both

92 McCabe v Ulster Bank Ltd \& others [1939] IT 1; see also discussions in "The Doctrine of Advancement: Its Application as between Mother and Child", above n 13.

93 Guardianship Act 1968 (repealed), s 6(1).

94 Section 21(1) of the Human Rights Act 1993 prohibits discrimination based on sex. Also see Palmer, above n 6, at 329; and Tey, above n 12, at 41 .

95 Nelson v Nelson (1995) 132 ALR 133. The Court was unanimous in this regard: see at 141 per Deane and Gummow JJ, at 162 per Dawson J, at 170 per Toohey J and at 183 per McHugh J. Toohey J discusses the pronouncements in Calverley $v$ Green and Dullow v Dullow at 170.

96 Pecore v Pecore, above n 68, at [33] per Rothstein J (for the majority) and [79] per Abella J.

97 See comments in Holster v Grafton, above n 34, at [19].

98 Tey, above n 12, at 51-52. Tey also discusses the extension to mothers in Canada, Australia and Singapore as of 2008 .

99 Close Invoice Finance Ltd v Abowa, above n 36, at [93]-[95].

100 Musson v Bonner [2010] WTLR 1369 (Ch) at [17]. 
camps, ${ }^{101}$ despite the fact that legislation had prescribed "exactly the same legal duties" on both parents to support and maintain the child. ${ }^{102}$

New Zealand seems to be more closely aligned with the United Kingdom than with Australia and Canada in terms of the application of the presumption to mothers. Similar to the United Kingdom, New Zealand courts progressed towards recognition of mothers with some dissenting voices. The High Court in a 1985 decision, Pyne Gould Guinness v Harkerss, examined relevant authorities and held that the presumption did not apply to a mother transferor. ${ }^{103}$ In 1992 the Family Court in Sutherland $v$ Wadham expressed doubt about this proposition, and noted that even if the presumption did not apply to mothers, "very slight evidence" was sufficient to establish intention to make a gift. ${ }^{104}$ By 2008, in Holster v Grafton the Court acknowledged that the Australian and Canadian approach was "inevitabl[e]" and held that the presumption applied to a mother, deliberately and explicitly departing from the earlier New Zealand decision in Pickens $v$ Metcalfe. ${ }^{105}$ Similarly, in a 2012 case, $D G H v P I H$, the Court readily extended the presumption to the mother. ${ }^{106}$ However, in the same year, an opposite approach was taken in another case, Evans $v$ Bonner, where the Judge noted that the presumption did not apply to a mother "unless the mother was in loco parentis". ${ }^{107}$ In that case, the mother transferred (including by weekly automatic payment) more than $\$ 550,000$ over a period of four years to the son while she lived with him, leaving very little in her estate when she died. While the context of the case may justify scrutiny of the son's action and the intention of the transfer, the requirement for a mother to be in loco parentis is a denial of a mother's guardianship provided for in the legislation. The clear rejection to apply the presumption of advancement to mothers was also a departure from the trend of judicial development in New Zealand courts. In 2017 the High Court in Zhang $v$ Li continued to note that whether the presumption should apply to mothers was a matter of debate. ${ }^{108}$

In most other cases, including cases involving mother transferors, courts simply referred to the presumption as between "a parent" and their child and did not distinguish between father and mother. ${ }^{109}$ Such cases gave no explicit discussion about the applicability to mothers, but the

101 Smith v Crawshay [2019] EWHC 2507 (Ch) at [65].

102 Glister, above n 69, at 377.

103 Pyne Gould Guinness v Harkerss HC Christchurch A148/84, 2 August 1985 at 8-12.

104 Sutherland $v$ Wadham [1992] NZFLR 455 (FC) at 460-461.

105 Pickens v Metcalfe [1932] NZLR 1278 (HC). See Holster v Grafton, above n 34, at [19].

106 DGH $v$ PIH, above n 49.

107 Evans v Bonner HC Whangārei CIV-2010-488-000335, 17 November 2010, at [18].

108 Zhang $v$ Li, above $\mathrm{n} 21$, at $\mathrm{n} 2$.

109 For example see Nelson v Meier [2016] NZHC 787; and Narayan v Narayan, above n 24. 
implication was that it applied. Although it was possible that the expression of "a parent" was an expediency, it was more likely that most judges did not consider it worth discussing the distinction between fathers and mothers, and the reason could be because the notion that mothers were equal parents with fathers has become well-recognised and fundamental in New Zealand.

Courts, therefore, in most cases have explicitly or implicitly accepted the elimination of any distinction between fathers and mothers in the application of the presumption of advancement, but the law has not been, and should be, settled.

\section{B Adult Children}

The debate about whether the presumption of advancement should apply to adult children can be seen most clearly in the Supreme Court of Canada's decision of Pecore $v$ Pecore. While acknowledging that the presumption provides guidance for courts and certainty for individuals, the majority in that case declined to apply the presumption to adult children because "a principal justification for the presumption of advancement is parental obligation to support their dependent children". ${ }^{110}$ The majority further refused to apply the presumption to dependent adult children because of the wide variety of circumstances that may arise and the uncertainty and unpredictability it may create. ${ }^{111}$ In contrast, the dissenting Judge, Abella $\mathrm{J}$, argued that resting the presumption on parental obligation alone "narrows and somewhat contradicts the historical rationale for the presumption", of which parental affection was an important factor. ${ }^{112}$ Her Honour would have allowed the presumption to apply to adult children without regard to financial dependency. ${ }^{113}$

Arguments of the majority and the dissenting Judge in Pecore v Pecore amply illustrate the root of the division, namely, the basis of the presumption - was it because of parental affection or parental obligation? ${ }^{114}$ Natural parental love and affection are inherent in the parent-child relationship, regardless of the age of the child. In contrast, although there have been references to the concept of "moral obligation", 115 the term "obligation" has a legal connotation and is increasingly so interpreted - it has been argued that where moral obligation is regarded as the basis for the presumption, any test would need to revert to legal requirements of family law. ${ }^{116}$ Since parental obligation to support or

110 Pecore v Pecore, above $\mathrm{n}$ 68, at [36] per Rothstein $\mathrm{J}$ for the majority (emphasis added).

111 At [39]-[41].

112 At [89]-[98] per Abella J.

113 At [98].

114 See Jamie Glister "The Presumption of Advancement" in Charles Mitchell (ed) Constructive and Resulting Trusts (Hart Publishing, Oxford, 2010) 289 at 295-296.

115 For example see Beenen v Beenen [2020] NZHC 3163 at [27] and [33]. The reference was about a moral obligation to repay the parents' money, rather than the parents' moral obligation to support.

116 Glister, above n 69, at 378. 
provide for their children stops at adulthood, it paves the way for rejecting the presumption of advancement for adult children. The unique relationship between a parent and their child is sometimes listed as a separate basis for the presumption, ${ }^{117}$ but that relationship may be seen as the source of parental affection and obligation. In fact, parental affection could be an alternative expression of a unique relationship, because where there was parent-child relationship, parental affection was assumed. No parent-child transfer case concerning the presumption of advancement has investigated the existence or degree of affection felt by a parent to his or her child. Therefore, the question becomes, is the unique parent-child relationship sufficient to invoke the presumption of advancement, or is parental obligation needed?

Palmer regards the presumption as applicable when "the relationship between A and B is such that there is a natural obligation for A to provide for B". ${ }^{118}$ This statement captures the two key factors: a relationship between the transferor and the transferee, and an obligation to provide. But the question remains: does falling within a certain relationship automatically give rise to an obligation to provide, hence triggering a presumption? ${ }^{119}$ Or does a relationship have to be to such a degree that it gives rise to an obligation to provide? The first possibility in effect requires only the unique relationship and the rest simply flows from that relationship, while the second requires an obligation to provide in addition to a certain relationship. Courts have approached this question differently.

In the first approach, courts assumed that, where there was a parent-child relationship, there was an obligation for the parent to provide for the child, and hence, the presumption was engaged. This approach regarded the unique relationship as dictating an obligation to provide. Among the cases surveyed, Woolf $v$ Kaye strongly advocated this view. In that case, Gordon $\mathrm{J}$ discussed the presumption at length, comparing the Pecore v Pecore approach to exclude adult children from the presumption and the United Kingdom approach to apply the presumption to adult children, regardless of whether they are dependent or not. ${ }^{120}$ Citing the dissenting judgment in Pecore v Pecore with approval and expressing support for the United Kingdom approach, her Honour argued that "parental or moral obligation to support" existed "irrespective of the age of the child, or whether they are independent or dependent." ${ }^{121}$ Her Honour further reasoned that the traditional rationale for the

117 See Tey, above n 12, at 43-44; Thomas, above n 81, at 85; and Palmer above n 6, at 328 .

118 Palmer, above n 6, at 328

119 In the Civil Law tradition, spouses, and parent and child, owe each other alimentary obligations by virtue of their relationship. See Katherine Connell-Thouez "The Family in Contemporary Civil Law - Comparative Developments in Alimentary Obligations and Parental Authority" (1986) 60 Tul L Rev 1135. I thank Professor Tony Angelo for drawing my attention to this.

120 Woolf v Kaye, above n 34, [163]-[202].

121 At [190]. 
presumption was both parental obligation to provide for their children and parental affection, ${ }^{122}$ as opposed to just one or the other. This essentially bundled parent-child relationship, parental obligation and parental affection together. It amounted to saying the existence of a parent-child relationship suffices. Lo $v$ Lo expressed the basis as parents' "devotion" to their children's interest. ${ }^{123}$

Most of the surveyed cases that applied the presumption of advancement simply applied it as a matter of course, given that the transfer was from a parent to their child, without mentioning any rationale for the presumption. This implies that the relationship of parent-child alone was sufficient to sustain the presumption. The outcome is that the presumption applies to adult children without qualification.

The second approach treated the obligation to provide as a separate requirement for the presumption to be engaged. This approach agreed with the majority in Pecore v Pecore in requiring parental obligation, but it has not abandoned the notion of dependency, which often arose in a roundabout way through the notion of in loco parentis. In loco parentis referred to a person who was not a natural parent but who stood in the place of a parent, but the new development required a natural parent to be in loco parentis for the presumption to apply. This in fact changed the definition of "in loco parentis" to impose a requirement of dependence between parent and child. For example, in Nelson $v$ Meier the court held that the presumption "applies between parent and child where the relationship is [sic in] loco parentis, i.e. the child is dependent on the parent." ${ }^{124}$ Although it is unclear whether the Judge was influenced by the fact that the transferor was a mother, as opposed to a father, the expression referred to "a parent" which meant that dependency was the key, regardless of mother or father. Under this approach, the presumption applies only to dependent adult children.

The factor of obligation to support could be so emphasised that the requirement for a unique relationship is overshadowed or excluded. In Mamat $v$ Mamat, the Court noted, along the line articulated by Palmer, that the presumption was engaged where the relationship between the parties was such that there was a natural obligation for one party to provide for the other. ${ }^{125}$ The Court was ready to apply the presumption as between brothers "if there was evidence pointing to an obligation" on the part of one brother to provide for the other. ${ }^{126}$ Although not directly impacting a parent-child relationship, this shift does highlight the importance of the notion of obligation and its role as a separate requirement, reflecting a move away from the discourse on affection and relationship.

122 At [189] (emphasis added).

123 Lo v Lo, above n 41, at [27].

124 Nelson v Meier above n 109, at [57]-[58].

125 Mamat $v$ Mamat, above n 31.

126 At [119]. The Court found no such obligation between the brothers in this case. 
In a 2019 decision, Reid v Castleton-Reid, the Court of Appeal leant towards this second approach. In that case, the father transferred nearly two million dollars to the adult son's account. The Court noted that "the presumption is based on the concept of parental obligation to support children." 127 This seemed to be intentionally countering the articulation of "both parental obligation and parental affection" in Woolf $v$ Kaye, which was decided the year before, but which Reid did not refer to. However, the expression in Reid v Castleton-Reid was less unequivocal than Nelson v Meier. The Court reviewed cases, including Pecore $v$ Pecore, without expressing a view on the approaches taken. It simply held that it was "difficult to see any rationale for the operation of the presumption of advancement where an adult child is well established in life" and decided the case on the evidence. ${ }^{128}$ Here the reference to "well established" leaves room for a different outcome should a less wellestablished but nonetheless independent adult child be the transferee. The term "parental obligation to support" was not expounded on and the Court avoided pronouncing on what it entailed or whether it was confined to financial support.

The resolute approach in Pecore $v$ Pecore to exclude the presumption from applying to adult children has not gained outright support in New Zealand. The exception was an obiter dictum in a 2019 High Court decision, where the Judge would have followed Pecore v Pecore "had it [the presumption of advancement] been raised as an issue in the case", which it was not. ${ }^{129}$ The Reid decision indicates it is likely that the presumption will continue to apply to dependent adult children and possibly apply to independent adult children who are not well established. The Court avoided consolidating or clarifying the law, and the answer to what constitutes dependency remains unclear.

In comparison, although Australian and United Kingdom courts remain divided on whether the presumption of advancement should apply to adult children, there have been more direct discussions on the point and clearer indication of views. The predominant view in Australia and the United Kingdom is that parental duty to support or an adult child's dependency is not a necessary requirement for the presumption to be engaged, and therefore, the presumption applies to adult children, although the adulthood and financial dependency are factors relevant to the strength of the presumption. ${ }^{130}$ As such the presumption was based on the unique relationship between a parent and a child. ${ }^{131}$ The opposite view to the above also exists in the United Kingdom, which is that the presumption of

127 Reid v Castleton-Reid, above n 34, at [85].

128 At [85]-[86].

$129 T N v A K[2019]$ NZHC 2466 at [68]-[69].

130 For example Anderson v McPherson (No 2), above n 57, at [129]-[130]; Lucas v Lucas [2018] NSWSC 962 at [160]-[162]; Laksar v Laksar, above n 36, at [20]; and Wood v Watkin, above n 30, at [91]-[93].

131 For example Nelson v Nelson, above n 95, at 140 per Deane and Gummow JJ and at 182 per McHugh J; Spink $v$ Flourentzou [2019] NSWSC 256 at [312]; Sze Tu v Lowe [2014] NSWCA 462, (2014) 89 NSWLR 317 at [179]; also see review of the authorities in Jagoda v Jagoda [2017] FamCA 1037 at [370]-[374]. 
advancement does not arise where there is no evidence to prove the parent is under an obligation to provide for an adult child, ${ }^{132}$ given that the legislation does not impose a general duty to provide.

Compared with the Canadian, Australian and United Kingdom judicial pronouncements, New Zealand courts indeed "glossed over" 133 or even avoided addressing the underlying rationales of the presumption, and therefore, left the question of whether the presumption applied to adult children without a clear answer.

\section{Children-in-Law}

The relationship between a parent-in-law and a child-in-law does not fall under the traditional categories of relationship, yet parent-child transfers often become an issue when the child's marriage or de facto relationship breaks down.

Many of the cases surveyed involved relationship property or relationship debt of the transferee. Parents supported their child for land purchase before or during the child's marriage; when the relationship broke down, the spouse or partner claimed relationship property while the child transferee claimed that his or her parent, who had advanced money to assist the purchase, had an interest in the property, or that the money transferred was a loan, hence the couple owed a relationship debt to the parents. The purpose was to exclude the partner from the parent's contribution. The parent-child relationship was thus entangled with relationship property issues. Out of the 83 cases examined, 38 involved one party alleging a proprietary interest or loan owed to parents after relationship breakdown. A further eight cases involved disputes between a parent-in-law and a child-in-law after the child passed away or the relationship broke down, and two of the cases between a parent and a child also concerned relationship property claims by the child's partner. In total, 48 out of 83 cases involved a child-in-law contending for an interest in a property of which a parent had contributed to the purchase. In contrast, only 11 cases involved a parent-child dispute (excluding the two cases whose real contestants were the child and their partner), and a further 10 concerned sibling disputes regarding parents' contribution or parents' estates. The remaining cases concerned criminal proceeds involving parents' contribution to property (10 cases) and social welfare (one case). The parent-in-law and childin-law situation is therefore a significant factor in parent-child transfers.

In Australia, transfers between a parent and a child-in-law give rise to the presumption of resulting trust, rather than the presumption of advancement. ${ }^{134}$ In Anderson v McPherson (No 2), the Judge refused to extend the presumption to a daughter-in-law because it was "not a recognised relationship

132 See for example Musson v Bonner, above n 100, at [13], [19] and [23]-[28]; and Voukidis v C \& O Voukidis Pty Ltd (In Liq) [2018] VSC 267 at [291].

133 Tey, above n 12, at 43.

134 Glister, above n 74, at 41. 
for the purposes of the presumption of advancement". ${ }^{135}$ Spink $v$ Flourentzou regarded it less justified to apply the presumption to a married child and held that the relationship between a parent on the one hand, and an adult child and the child's spouse jointly on the other, did not fall within the established category. ${ }^{136}$ The Judge also rejected the notion that the presumption may apply to the child for half of the transfer. ${ }^{137}$ The exception is when the parent stands in loco parentis to the child-in-law, which essentially falls in the in loco parentis category and is no longer a child-in-law situation. ${ }^{138}$

In New Zealand, scholars also deem it settled law that the presumption does not apply to a childin-law. ${ }^{139}$ Earlier cases were clear on this point. Knight $v$ Biss held that the presumption did not apply to a son-in-law unless the father placed himself in loco parentis to the son-in-law. ${ }^{140}$ Pyne Gould Guinness $v$ Harkerss similarly noted that the presumption was not applicable to a son-in-law. ${ }^{141}$ Yet cases in the last 20 years have paid no attention to this position and the issue has been little, if at all, discussed in the cases surveyed. Among the cases that involved monetary transfers during the child's marriage or de facto relationship, only one case specifically touched on the applicability to a child-inlaw. The others simply applied or discussed the presumption without addressing, one way or another, the issue of in-laws. Those cases could be divided into three categories.

The first approach is to apply the presumption as a matter of course and hold that the presumption was not rebutted, and thus the parents' transfer was held to be gifts to the young couple. Examples in this category included $D G H v P I H$, where a mother advanced $\$ 90,000$ out of $\$ 97,000$ sales proceeds of her own house for the purchase of property by her daughter and son-in-law; and Zhou v Yu, where parents transferred more than half a million dollars to the son and daughter-in-law for the purchase of property. ${ }^{142}$ In both cases the Court held that the transfers were gifts. The Court did not specify whether the presumption applied to the child which then rendered the money or property relationship property by virtue of the Property (Relationships) Act or whether the presumption applied to the young couple together. The latter - applying the presumption to the couple together - is beyond the original design of the presumption of advancement. The rationale of the presumption, be it natural affection, natural obligation or unique relationship, cannot be taken for granted as between a parent-in-law and

135 Anderson v McPherson (No 2), above n 57, at [143].

136 Spink v Flourentzou, above n 131, at [311]-[312].

137 At [309]-[312].

138 See Jagoda v Jagoda, above n 131, at [375]-[390].

139 Palmer, above n 6.

140 Knight v Biss [1954] NZLR 55 (SC) at 57.

141 Pyne Gould Guinness v Harkerss, above n 103, at 12.

142 DGH v PIH, above n 49; and Zhou v Yu, above n 50. 
a child-in-law. Yet it is artificial to say that the transfer was to the child alone, an assumption that the Australian courts have refused to make.

The second category similarly applied the presumption as a matter of course and differed from the first category only in the outcome. In these cases, courts often found slight evidence to rebut the presumption. ${ }^{143}$ The result in these cases may have been because of the weakness of the presumption itself, or may have been driven by the Judge's uneasiness to allow the spouse or partner to deprive the parents of their contribution. The issue is the same outcome to the cases could have been achieved by refusing to apply the presumption where a child-in-law is involved, as was done by Australian courts.

A third approach chose not to engage the presumption because it was a legal anachronism or was a last resort and did not turn on the sub-issue of whether it applied to children-in-law. For example, in Young $v$ Young the presumption was not engaged because the dispute was about a loan or a gift instead of a trust issue. ${ }^{144}$ In Narayan $v$ Narayan, the Judge preferred turning the attention to the validity of an "irrevocable document" rather than applying the presumption. ${ }^{145}$ In Linton v Millar, the Court similarly inferred an intention for repayment from circumstance, namely, prior loans. ${ }^{146}$ These cases therefore avoided the issue of whether the presumption applied to a child-in-law or the young couple together.

The only case found to have mentioned the applicability of the presumption to a child-in-law was Terry Schwass Co Ltd v Marsh. ${ }^{147}$ In that case, the Judge avoided applying the presumption by pointing to the fact that the son admitted it was a loan and so the presumption was displaced, while the daughter-in-law accepted that the presumption did not apply to her. ${ }^{148}$ DGH and Zhou v Yu would have achieved a completely different outcome if the approach in Terry Schwass Co Ltd v Marsh was taken. Terry went a step further than the other cases which applied the presumption without analysis, but there was still no discussion about whether the presumption applied to a child and his or her partner together, as was done in the Australian case of Spink v Flourentzou.

\section{Summary}

In summary, New Zealand law lacks certainty and clarity about the application of the presumption to mothers, and courts have been divided on whether it applies to adult children. Almost no

143 For example $A D M v D J N$, above n 40, at [59]; and $K B M v R M$, above n 39, at [22]. See Part IIC of this article for the discussion on the easy rebuttal of the presumption.

144 As discussed in Part IIIB.

145 Young $v$ Young, above n 19; and Narayan v Narayan, above n 24.

146 Linton v Millar, above n 51, at [18].

147 Terry Schwass Co Ltd v Marsh [2017] NZHC 1382, [2017] NZCCLR 19.

148 At [21]. 
consideration has been given to the applicability of the presumption where a child-in-law is involved, an issue that should not be neglected given that relationship property disputes occupied most of the cases concerning parent-child transfers.

\section{CONCLUSION}

The presumption of advancement is a doctrine invented by the judiciary to displace the presumption of resulting trust in cases of gratuitous transfers from husbands to wives, and parents or those in loco parentis to a child. Domestic and overseas jurisprudence shows that the conceptual framing and the application of the doctrine have been adjusted in recent decades. In New Zealand, there has been lingering support for the doctrine. However, the doctrine has also become increasingly marginalised, in that most cases concerning parent-child transfers ignored or bypassed the doctrine. When the doctrine was engaged, in most cases it was easily rebutted, indicating the weak status of the doctrine.

More critically, cases have largely been devoid of engagement with the doctrine, resulting in differing understandings and inconsistent applications. The conceptual questions about the nature of the doctrine, its relationship to the presumption of resulting trust and the effect of the Torrens registration system have been little discussed, as with questions about whether the doctrine applied to mothers, adult children and children-in-law. This inevitably resulted in inconsistent approaches in cases. Inconsistencies existed in aspects concerning the timing of application, the standard for rebuttal and applicable categories of persons. These could affect the outcome of cases as well as certainty in the law. It is recommended that, when opportunities arise in the future, New Zealand's higher courts lay down a clear and consistent approach regarding the doctrine so as to guide both the public and the courts. The marginalised and weakened status of the doctrine and the confusion in the cases also raise a question of the desirability of retaining the doctrine. 